\title{
顔面表情筋の神経支配に関する 誘発筋電図学的研究(前編)
}

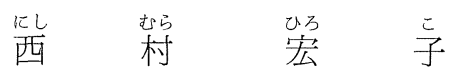

研 究目 次

(前編)

はじめに

第一節 実験装置と実験方法

第二節 臨床例における顔面神経交叉支配の検討

第三節 正常人における顔面神綠交文支配の検討

第四節 動物における顔面神経交文支配の検討
(後編)

はじめに

第一節 顔面正中部誘発筋電図の意義一正常人の検討 第二節 顔面正中部誘発筋電网の意義一顔面神経麻痺 例の検討

全編の考按

全編の結語

\section{はじめに}

顔面表情筋に抬ける神経支配については，前頭部筋群は両側大脳皮質運動領の支配をうけ，その 他の筋は反刘側皮質運動領の支配をうけているとするのが神経学の常識である。顔面神経の末梢に

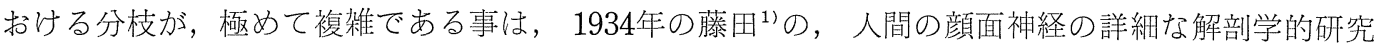
によって示されているが，顔面の正中部近傍での顔面神経の支配については，例えば，交軖性支配 があるのか，とれとも，厳密に㴜側性支配であるのかに関しては，未だ充分な解明がなされていな い. 一方臨床的には，末杪に扣ける顔面神経の完全な切断後におこる表情機能の自然的回復は，三 叉神経と顔面神経の間の交通枝に由来する三叉神経運動枝の再生によるとするすの，反対側の顔面 神経よりの再生によるとする考えなどがあり，統一的見解に至っていない，著者も，顔面神経麻痺 患者の経過を観察していると，表情筋の神経支配に関する教科書的知識では到底説明不可能な現象 を㷴々経験して来た。

以上の理由から，本編に执いては，臨症例，正常人，動物（猫及び家鬼）について，主として誘 発筋電図法を用いて，表情筋の顔面神経支配について系統的研究を行ったので報告した。

\section{第一節＼cjkstart実験装置及び実験方法}

人間及び動物に一貫して使用した実験装置の ダイヤグラムを図1に示した。

筋活動電位は針（1 針同心又は 2 針同心), または表面電極により, 三栄測器製生体電気増
幅器に導かれ, この増幅器の出力は, 一方では Hewlett Packard 1207A 可変蓄積型オシロス コープによりモニターされ, 他方で, 三栄測器製 平均加算ミニコンピューター (Signal Proces-

Evoked Electromyographic Investigation on Innervation of the Facial Muscles ( I). 


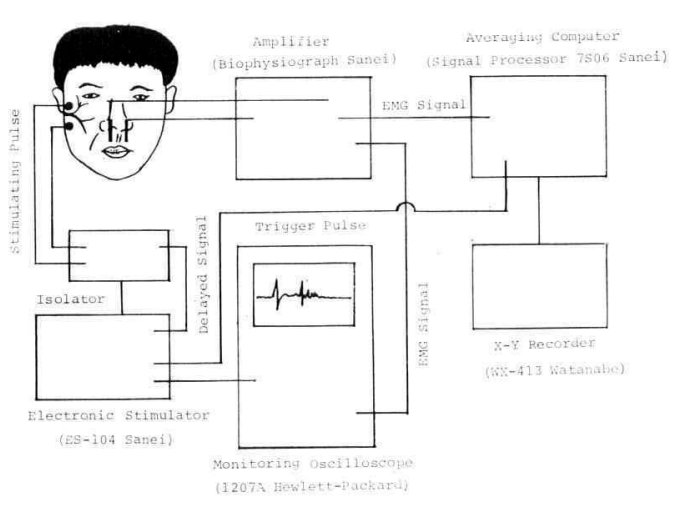

図１実験装置と方法

sor 7S06）に導かれ汇憶された。

顔面神経に対寸る電気刺激は，電子管刺激装 置（三栄測器 E S 104）により与えられた。矩 形波刺激の持続時間は，0.3msec に一定し，

刺激頻度は 1 秒間に 1 回とした。電気刺激に 4 msec 先だって, 電子管刺激装置より Monitor Oscilloscope およびミニコンピューターの外 部掃引回路に trigger pulse が与えられた。従 って, 刺激波は, 誘発筋電図上で掃引開始より $4 \mathrm{msec}$ 遅机た artifact として記録されるの で, 神経に与えられた電気刺激と, それによっ て誘発される筋活動電位の関係が明膫に観察さ れた。刺激電極を耳車下部で, 茎乳咨孔考顔面 神経が出る部位で，乙扎をはさむ様に置き，神 経を経皮的に電気刺激した。通常人間では20 50回誘発反応老加算し, 動物では100回の加算老 行い, X-Yレコーダー(ワタナベ WX-413) により描䛉記録した。

尚, 誘発筋電図の記録に際して, 室温在 $25^{\circ} \mathrm{C}$ に一定する様に注意した。

\section{第二節＼cjkstart臨床例における検討}

1972年 2 月 9 日, 著者等は錐体尖端部に生じ た真珠腫による再発性顔而神経麻瘦の例に, 経 乳突, 経中頭蓋窝法により顔面神経移植術在行 った。術後，たまたま 1 針同心電極を用いて， 患側上口唇部でロ輪筋の筋電図記録老試みたと ころ, 患側顔面神経は切断されているにもかか わらず予想外に大きい干渉波が記録された（図 2 B). そこで, 試みに健側顔面神経在電気刺 激し誘発筋電図を観察したところ(四2 A) 。健 側に比べ潜時の長い誘発電位を認め, 患側い輪 筋が健側の顔面神経の支配を受けている事在知 った(図 $2 \mathrm{C}$ ).

その後, 類似の症例において, 健側よりの神 経支配を示唆する現象が輪筋のみならず，顔 面正中近浐の諸筋に求いても記録された。この 様な現象老端的に示す代表数例についての研究 結果在以下に示す.

\section{症例 1}

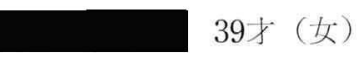

11才より右慢性中耳炎に罹患, 31 才の時, 右 中耳根本手術をうけた。術直後より右顔面神経 麻痖をきたしたが放置していた。炤和50年11月

\section{刺入電極の位置}

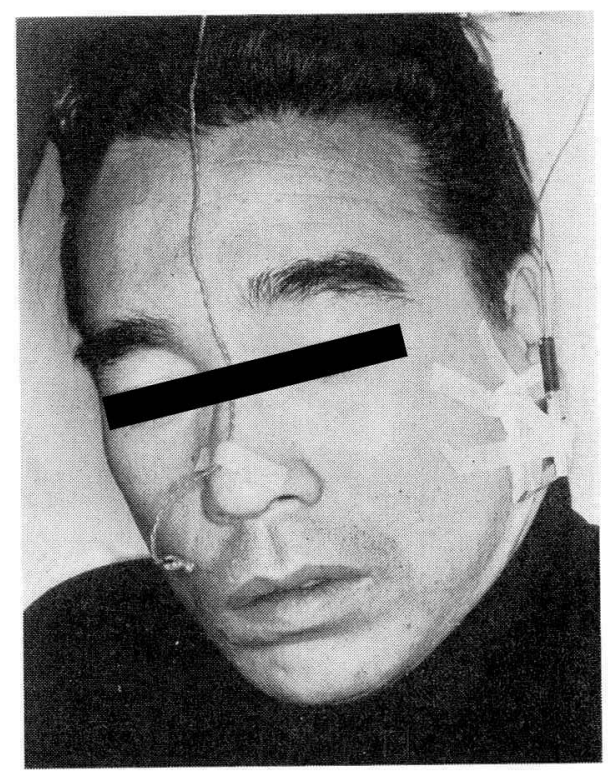

図2(A)

頭重感, 耳漏が増強し, 錐体部真珠腫症の診断 の屯とに, 昭和 50 年 12 月 4 日, 迷路全剔出, 錐 体尖開放術により真珠腫を剔出した。この時, 膝神経節から垂直部にかけ約 $3 \mathrm{~cm}$ 顔面神経在切 
筋電図

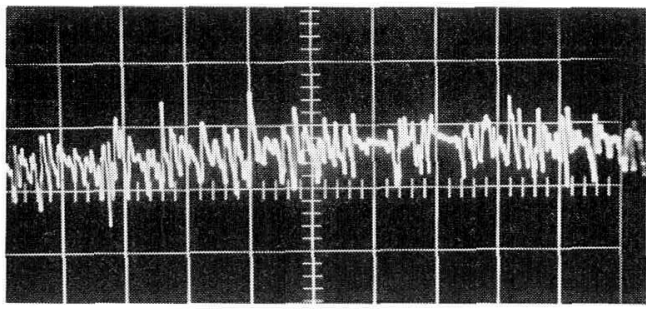

図 $2(\mathrm{~B}$

誘発筋電図

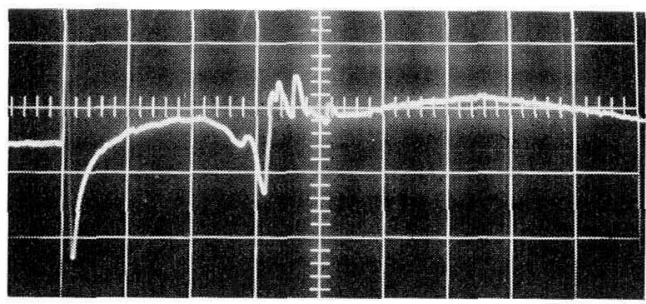

図 2 (C)

断した。切断神経の組織診断により，神経は角 化変性していた事が判明した。術捘も顔面麻瘏 程度は变らず，図 3 亿示す程度の患側表情筋の 収縮能を認めた。術後 1 ケ月目に筋電図検查在 行った.筋電図記録は表面電極によった.前頭筋 では，強い随意収縮時に健側では平均 $180 \mu \mathrm{V}$, 患側で平均 $20 \mu \mathrm{V}$ の筋電位が記録された。眼輸 筇涙蓑部では図 4 亿示す如く弱い随意収縮特に は健側は平均 $136 \mu \mathrm{V}$, 患側は平均 $30 \mu \mathrm{V}$, 强 い随意収縮時では健側で平均 $500 \mu \mathrm{V}$ ，患側で 平均 $60 \mu \mathrm{V}$ の箭放電を記録した。下眼臉部で は，健側では弱い閉眼では平均 $107 \mu \mathrm{V}$, 強い 閉眼では平均 $650 \mu \mathrm{V}$, 患側では弱い閉眼では ほとんど䈈電位の増強老認めず，強い閉眼では 平均 $89 \mu \mathrm{V}$ の筋電位在記録した。煩部に执いて は，強い収縮により健側では平均 $50 \mu \mathrm{V} の$ 筋電 位在䛉録したが，患側においては，強い収縮に おいても筋電位を記録しえなかった。口輪筋に おける筋電図を図 5 に示す。最上段に示ず如く 健側，患側と屯ごくわずかに resting potential が認められ，軽い口唇のつき出し運動により， 中段に示す様に，健側では平均 $467 \mu \mathrm{V}$ ，患側

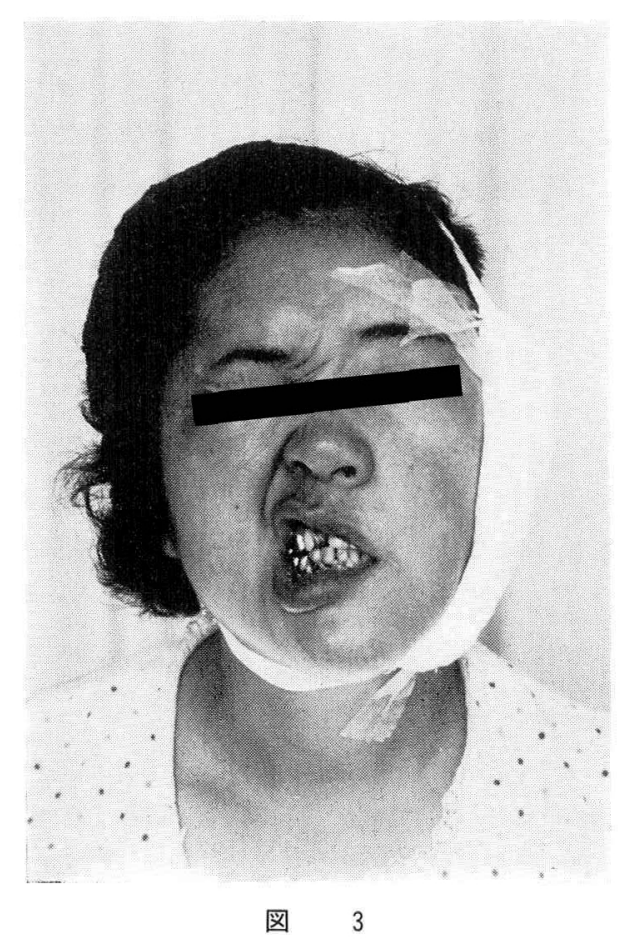

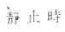

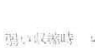

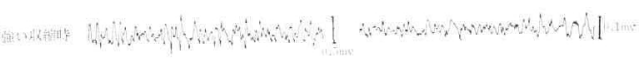

図 4 腿輪筋涙囊部に扔け万筋電図(表面電極に よる) 症例：39才 (ㅇ) 左真珠腪による顔 面神経麻㥏. 左顔面神䌊切断後 1 万月.

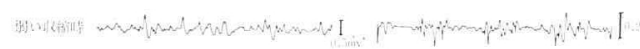

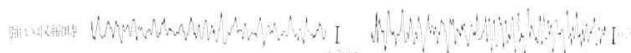

図 5 口輪筋に扔ける筋電図（表面電極による） 症例：図 4 之同し。

では平均 $133 \mu \mathrm{V}$ の筋電位老認め, 強く口唇在 つき出させると, この電位は健側で $708 \mu \mathrm{V}$, 患側では $567 \mu \mathrm{V}$ に増強した。すなわち， 口輪 筋では強い収縮で平均振幅に著明な左右差を認 
めなかった。

次に右の顔面神経刺激に対する左右の顔面筋 の誘発筋電図について検討した。眼輪筋涙霊部 より表面電極にて記録した誘発筋電図を図 6 に

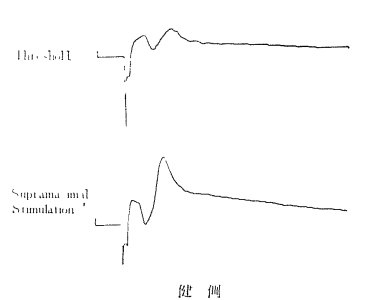

继例

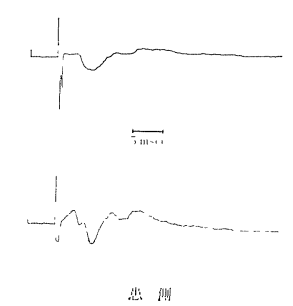

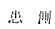

図 6 健側顔面神経刺激による誘発筋電図（表面 電極による) 症例：図 4 と同じ.

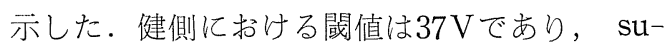
pramaximum の刺激閾值は $60 \mathrm{~V}$ であった。患 側に氺いては閾值は $24 \mathrm{~V}$ であり supramaxi-

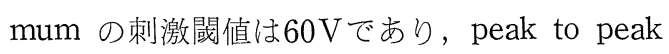
の振幅は健側で $1,760 \mu \mathrm{V}$. 患側で $173 \mu \mathrm{V}$ で あった。口輪筋に打いては, 健側の閾值は 37 $\mathrm{V}$ ，患側では同じく37V， supramaximum の 刺激閾值は健側では $100 \mathrm{~V}$, 患側では90Vであ り，振幅は健側 $1,493 \mu \mathrm{V}$, 患側 $1,067 \mu \mathrm{V}$ であ った。本症例に扣ける臨床観察, 筋電図之誘発 筋電図所見は, 顔面神経切断後でも, 随意収縮 時に筋電位の発射が認められ，乙の電位は反対 側よりの神経支配に由来する屯のである事を示 した。

次に，正中線からどの位離れた所まで反対側 よりの神経支配が存在するかという点について 検討を行った。健側耳垂下部で茎乳乫孔から出 る顔面神経幹をはさむ様に刺激電極をおき，ま ず，1針同心電極を上口唇正中部に刺入，口を つき出させて筋放電の最屯強く認められる部位 に電極を固定し，誘発筋電図を記錄した，次い で同様の手続きを行い，正中より反対側へ 0.5 $\mathrm{cm}, 1.0 \mathrm{~cm}, 1.5 \mathrm{~cm} \cdots \cdots$ と $5 \mathrm{~mm}$ 間隔每に, 電極針 を刺入し, 正中より何 $\mathrm{cm}$ 離れた所まで誘発反応 記録が可能かをみた (図 7 参照)。各点におけ る反応潜時を計測すると, 正中で $4.6 \mathrm{msec}$, $1.0 \mathrm{~cm}$ 反対側で $5.2 \mathrm{msec}, 1.5 \mathrm{~cm}$ で $7.2 \mathrm{~m}$

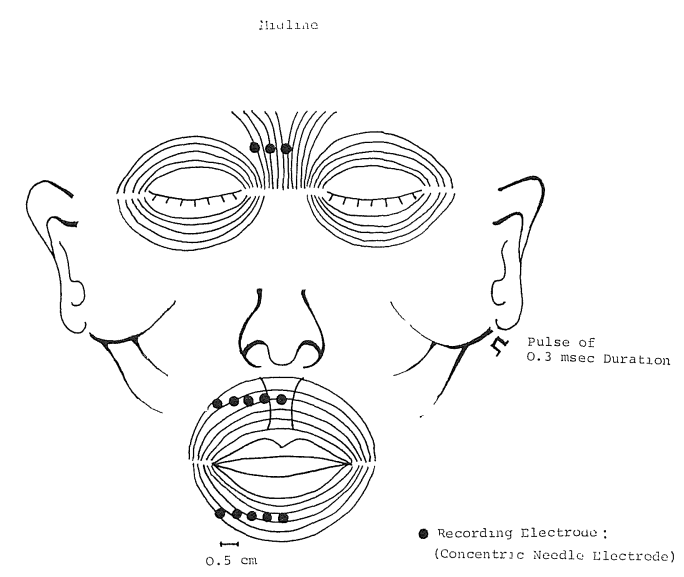

図 7 記録電極：1 針同心電極.

$\mathrm{sec}, 2.0 \mathrm{~cm}$ で $10.2 \mathrm{msec}, 2.5 \mathrm{~cm}$ では 11.2 $\mathrm{msec}, 3.0 \mathrm{~cm}$ では $13.2 \mathrm{msec}$ であり, $3.5 \mathrm{~cm}$ では刺激をいくら強くしても誘発電位は認めら れなかった。誘発電位の振幅は正中線を離れる に従って小さくなった。

以上の実験より，上口唇において 1 針同心電 極で認められた筋電位は正中線より $3 \mathrm{~cm}$ 離れた 所迄存在する事が示された。本例では, 神経受 傷後 8 年を経過し, 切除した神経の組織には神 経線維が認められない事から，上記の反対側よ りの支配は, 反対側顔面神経の末端からの再生 現象之も考えられ, 検討の要がある.

症例 2

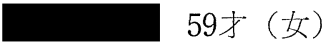

$5 \sim 6$ 年前より特に誘因なく左顔面半側に痤 變がおこり, その程度は次第に増強し, 最近で はほとんぞ左側の眼をあけている事ができず, 口唇, 煩部に屯痤攣が持続するようになった。 炤和50年11月27日. 左顔面神経切断術, 顔面神 経副神経吻合術を施行した。術後の表情筋機能 を示す顔写真を図 8 に示した。

術後40日目に, 誘発筋電図検査を行った。 図 9 亿示す如く, Aから Gまでの各部位に左右対 称に表面電極を貼り，健側（右）顔面神経を刺 激し，てれらの各部位からの誘発筋電図を記録 した，点 $\mathrm{H}$ は咬筋に一致する部位でありコント ロールとした、各導出部位で電位を記録する筋 
名を図 9 の下に示した。各部位で記録された誘 発筋電図在図10に示し，乙れらの潜時，振幅及 び患側振幅の健側振幅に刘する割合（以下振幅 Oと呼方）在表 1 に示した。以上の結果は以下 の如くまとめる事が出来る。

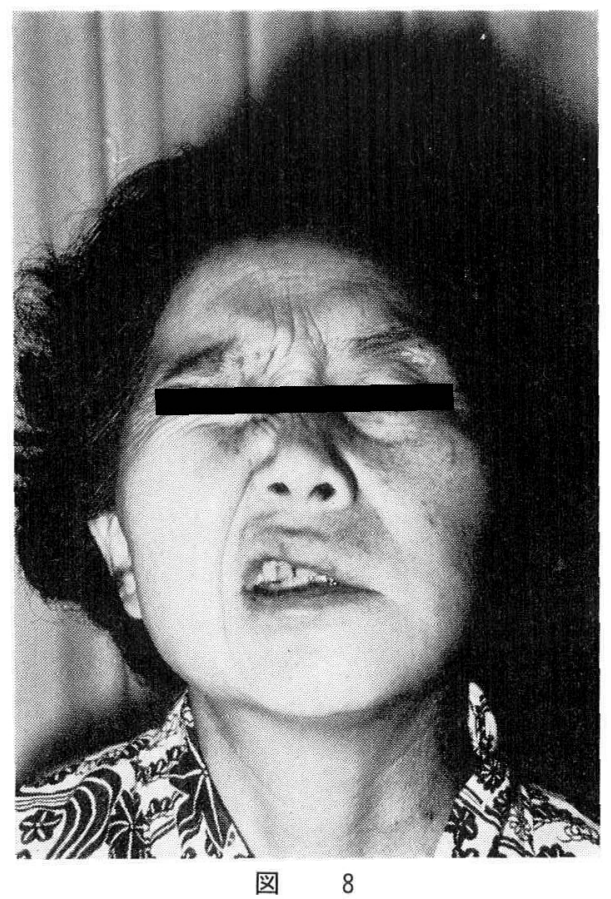

(1) 前頭笳(A)以外は，多少の差はあれ神経切 断側の筋に誘発電位が認められた。

(2) 左右の潜時在比較すると, D (眼輪)， E

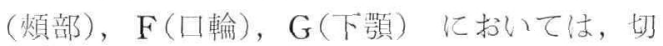
断側に明らかな延長老認めた。

(3) 振幅圭比較すると，A（前頙）は 0 ， D (煩部) は $2.7 \%$ で, 健側に比較してほとんど 無視しうる程度であるが，F（口輪筋）ではほ とんど左右差がなく, B (眉間), $\mathrm{E}$ (煩部),

$\mathrm{G}$ (下顎), C (眼輪筋涙囊部) の順に振幅 \% は小さくなっている。

次に症例 1 と同様に 1 針同心電極を用いてい 輪筋において，正中線を越えてどの程度反対側 まで顔面神経支配が及んでいるか在検討した。 上口唇に执いては，正中線より $1.5 \mathrm{~cm}$ 反対側ま

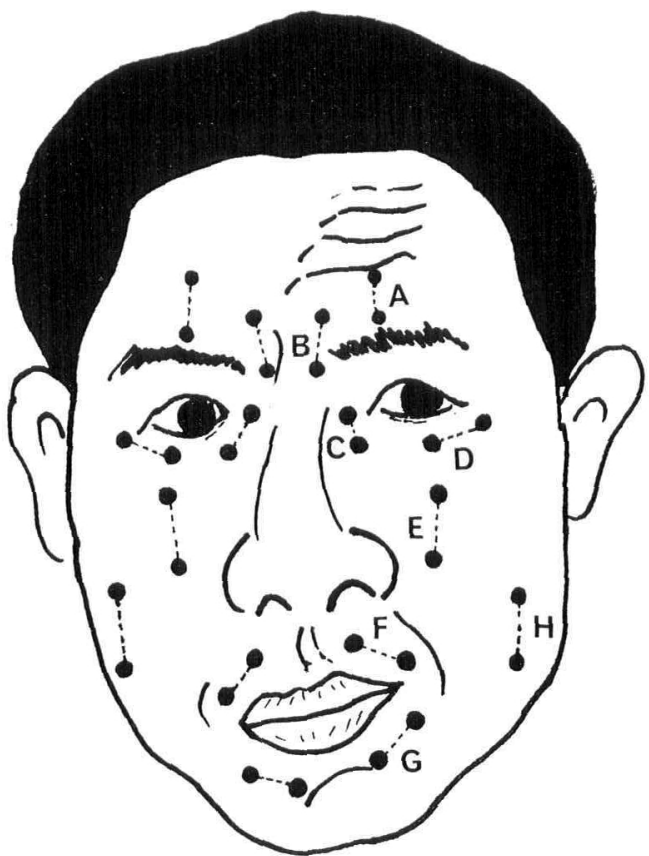

A : Fronta]

B : Depressor Glabella

C : Orbicularis Oculi (Pars lacrimalis)

D : Orbicularis Oculi (Pars orbitalis)

E : Zygomaticus Major and Minor

F : Orbicularis Oris

G : Orbicularis Oris and Inferior Depressor Labii

$\mathrm{H}$ : Masseter Control)

図 9

で，下ロ唇に扔いては，2.0cm まで誘発電位が 記録された。上唇の各部位にお括る潜時は， 正中線で $4.4 \mathrm{msec}, 1.0 \mathrm{~cm}$ 反対側, $5.8 \mathrm{msc}$, $1.5 \mathrm{~m}$ 反対側, $7.2 \mathrm{msec}$ 症例 1 の場合之同様に 正中線を離机るに従って, 潜時は延長した。ま た，振幅も正中線老離机るに従って縮小した。 症例 1 では顔面神経は 8 年前, 既に損傷をう けており, 最近行わ机た于術時の切断は, 誘発 筋電図の成績にほ上んど影響はないと考元られ る. 本例では正常に機能していた顔面神経の切 断後の成績走すすので, この成績から, 表情 筋に求ける反対側上りの神経支配は正常人にお いても存在し得る事走示唆している。 
症例：59才（ㅇ）左顔面神経切断後40日

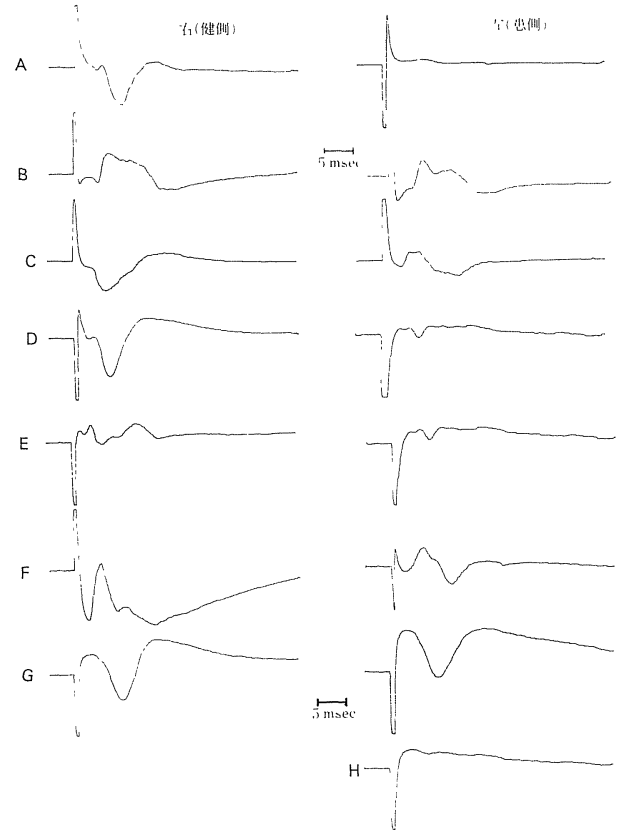

図10 各部位における誘発筋電図（表面電極による）

\section{症例 3}

52 才（女）

幼小時より両側慢性中耳炎に罹患. 昭和 36 年 9 月 9 日（38才の時）左中耳根本手術をうけ

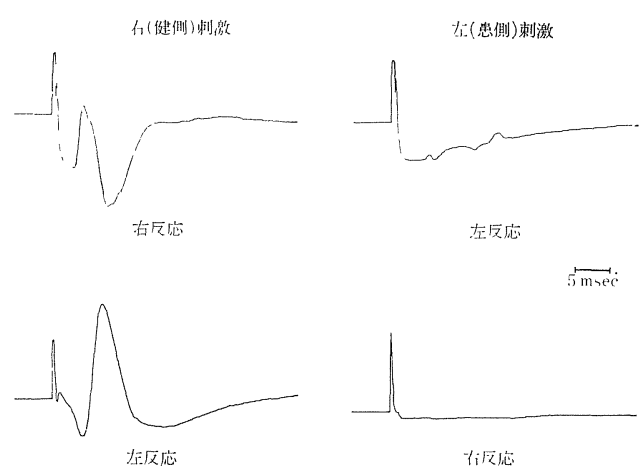

図川口輪筋における誘発筋電図（表面電極によ る) 症例：59才（ㅇ）14年前上り左術後性顔面 神终麻痺。

た.その直後より左顔面神経全麻盘をきたし た。麻瘏は発症 1 年後には不完全治癒のまま固 定し, 痤直, 病的共同運動等の神経再生過誤現 象を残した。

本例の口輪筋の誘発筋電図を図11に示し, 眼 輪筋の誘発筋電図を図12に示した。上段はそれ ぞれ同側の顔面神経刺激に対する誘発電位であ り，下段は反対側の顔面神経刺激に対する誘発 電位である. 図11に示す口輪筋誘発筋電図で は，患側（左）の顔面神経刺激に対しては，患 側, 健側と屯に誘発反応は微弱であり, 健側

表 1

\begin{tabular}{|c|c|c|c|c|c|}
\hline & 健 & 側 & 患 & 側 & \\
\hline & $\begin{array}{l}\text { 潜 時 } \\
(\mathrm{msec})\end{array}$ & $\begin{array}{c}\text { 振 幅 } \\
(\mathrm{mV})\end{array}$ & $\begin{array}{l}\text { 潜 時 } \\
(\mathrm{msec})\end{array}$ & $\begin{array}{c}\text { 振 幅 } \\
(\mathrm{mV})\end{array}$ & 振幅 \\
\hline A & 3.8 & 0.68 & & 0 & 0 \\
\hline B & 4.0 & 0.60 & 4.0 & 0.52 & 86.7 \\
\hline C & 3.2 & 0.62 & 3.2 & 0.21 & 33.9 \\
\hline D & 4.0 & 1.88 & 4.6 & 0.05 & 2.7 \\
\hline $\mathrm{E}$ & 3.2 & 0.32 & 4.8 & 0.16 & 50.0 \\
\hline $\mathrm{F}$ & 4.4 & 1.04 & 5.2 & 1.20 & 115.4 \\
\hline G & 4.0 & 0.52 & 4.4 & 0.2 & 38.5 \\
\hline $\mathrm{H}$ & 0 & 0 & 0 & 0 & 0 \\
\hline
\end{tabular}

振幅 $(\%): \frac{\text { 患側の最大振幅 }}{\text { 健側の最大振幅 }} \times 100$ 


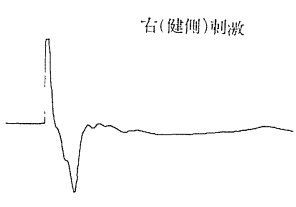

右反忍

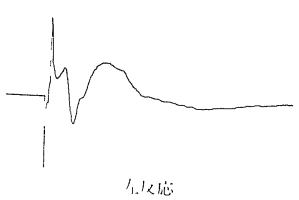

1.人他

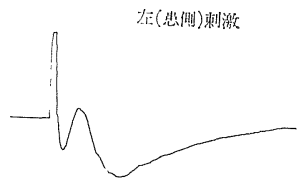

左反応

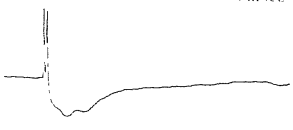

治反応
図12 眼輪筋における誘発筋電図（表面電極によ る) 症例：図11と同じ.

（右）の顔面神経刺激に対しては，健側におい ても，患側においても大きな誘発反応が記録さ れている。健側刺激に対する健側反応の潜時は $3.2 \mathrm{msec}$, 患例反応の潜時は $4.4 \mathrm{msec}$ であっ た. 次に眼輪筋においては。四12に示す如く, 患側眼輪筋は同側顔面神経刺激にかなり良く反 応し. 健側顔面神経刺激にも同程度の反応を示 した。一方，健側においては同側の顔面神経刺 激に対する反応に比べて患側の刺激に対する誘 発反応は微弱であった。

以上の結果は, 患側の口輪筋は主として健側 の顔面神経支配圭うけており, 患側眼輪筋では 健側加ら屯患側からも神経支配をうけている 事, 健側口輪筋, 眼輪筋は健側顔面神経のみの
支配をうけている事を示している.

\section{症例 4}

\section{1才（男）}

生下時, 口唇形成術を施行したが不満足であ ったので，炤和50年12月 9 日，再び口唇形成術 (Millard's Method) を行った. 術後 1 カ月 目に, 上口唇亡下口唇について誘発筋電図検查 を行った。図13は，表面電極により導出した誘 発筋電図である，上口唇では，同側顔面神経刺 激に対する誘発電位が記録されたが，洀良を境 にして反対側からは誘発電位がえられなかっ た。これに対し，下口唇に扔いては反対側から あ同側とほとんど同じような誘発電位がえられ た. 次に，1針同心電極により誘発筋電図を記 録した. 図14に示す如く, 同側（左）の上口唇 に扔いては誘発電位が記録されたが，瘢痕の直 上（正中線より $0.5 \mathrm{~cm}$ 反対側），およびさらに $0.5 \mathrm{~cm}$ 反対側においては誘発電位は記録されな かった。しかし，下口唇に㧊いては，正中を越 えて $1.0 \mathrm{~cm}$ 反対側においても潜時の延長した誘 発電位が記録された。

本症例の結果は，上口唇における口輪筋切断 により正中を越えて反対側を支配する顔面神経 末梢が切断された事を示している。

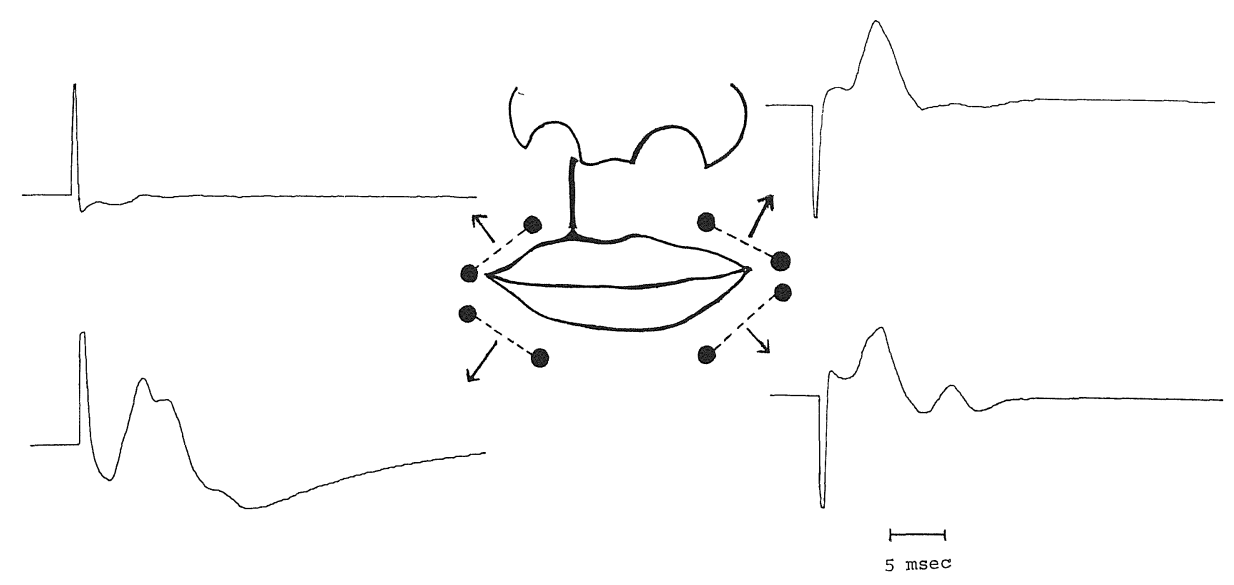

図13 左顔面神経刺激による誘発筋電図（表面電極による）症例：61才（令）口唇形成術 1 力月後 


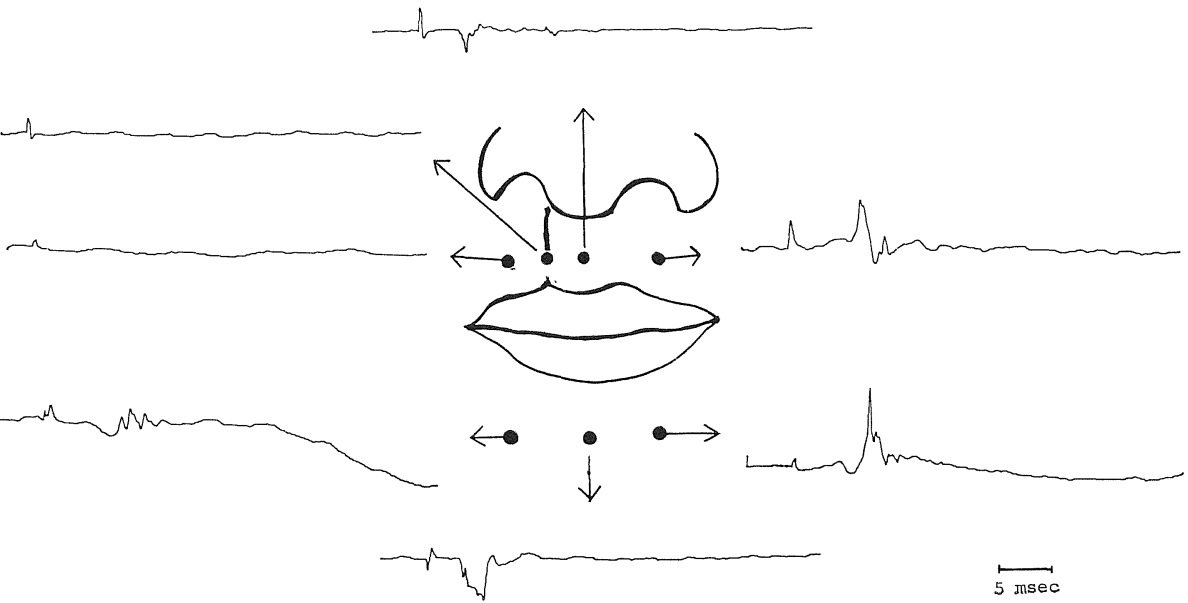

図14 左顔面神径刺激による誘発筋電図（1 針同心電極による）症例：図13と同じ.

〔小括〕

1 側顔面神経完全切断例， 1 側顔面神経の高 度損傷後再生を示した症例，1側口輪筋切断例 の筋電図, 誘発筋電図検査により以下の事が示 された。

（1）顔面表情筋は，正中部近傍では反対側の顔 面神経末梢部からあ神経支配をうけている。乙 の反対側からの神経支配は，口輪筋において最 屯顕著であり, 眼輪筋涙囊部, 眉間部の筋群等
の顔面正中部近傍の諸筋においても著明であ る.

（2） 1 側顔面神経が強い損傷をうけた場合，反 対側よりの神経が顔面の緊張維持, 運動に一定 の機能を発揮して抢り，神経切断後に起る顔面 表情筋の自然的機能回復には，反対側よりの神 経からの再生現象が関与している可能性があ る。

\section{第三節＼cjkstart正常人における検討}

\section{〔実験方法】}

正常人 26 名（22７1才，男 12 名・女 14 名）に ついて，臨床例において認められた口輪筋，眼 輸筋等における反対側顔面神経支配の実態につ いて，顔面神経の伝導速度測定などを行い詳細 に検討した。特に口輪筋においては症例 $1 ， 2$ に行ったの之同様の方法で 1 針同心電極を，上 口唇と下口唇のそれぞれ正中線上，及び刺激の 反対側に向って正中線より $0.5 \mathrm{~cm}, 1.0 \mathrm{~cm}, 1.5$ $\mathrm{cm}, 2.0 \mathrm{~cm}, 2.5 \mathrm{~cm}, 3.0 \mathrm{~cm}$ の部位に刺入し, 誘 発筋電図を記録解折した。

〔実験結果〕

上口唇における口輪筋の代表的誘発筋電図を
図15に示した。本例では図に示す如く，正中線 から $2.5 \mathrm{~cm}$ 反対側まで誘発電位がえられた。 反 応潜時は，正中線で $4.4 \mathrm{msec}, 0.5 \mathrm{~cm}$ 反対側で $4.8 \mathrm{msec}, 1.0 \mathrm{~cm}$ で $5.2 \mathrm{msec}, 1.5 \mathrm{~cm}$ で 9.2 $\mathrm{msec}, 2.0 \mathrm{~cm}$ で $11.6 \mathrm{msec}, 2.5 \mathrm{~cm}$ で $13.6 \mathrm{msec}$ と, 正中を離れるに従い潜時の延長が認められ た。、 又，振幅む正中を離れるに従って縮小し た。下口唇に括ける誘発筋電図の代表例を図 16 に示した。本例では，正中線から $2.0 \mathrm{~cm}$ 反対側 まで誘発電位がえられ，上口唇に見られた如く 正中を離れるに従い潜時は延長し，振幅は縮小 した。

全被検者に执いて，反対側何 $\mathrm{cm}$ まで誘発筋電 


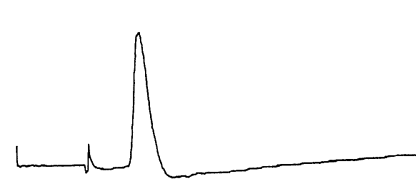

録電極の位琵

上丨暿止中

\section{$\stackrel{\mathrm{msec}}{\longrightarrow}$}

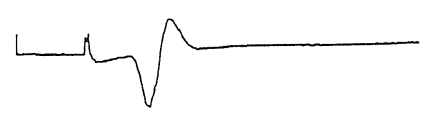

汇:中線より

$0.5 \mathrm{~cm}$

対僛

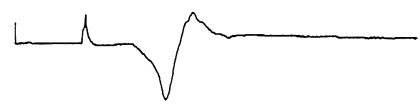

$1.0 \mathrm{~cm}$

$1.5 \mathrm{~cm}$

$2.0 \mathrm{~cm}$

$2.5 \mathrm{~cm}$

$3.0 \mathrm{~cm}$

図15 口輪筋（上口唇）における誘発筋電図 (1 針同心電極による)

図が記録されたかをまとめると，上口唇におい ては, 図17に示す如く $2.0 \mathrm{~cm}$ までが最む多く 12 名 $(46.2 \%)$, 次いで $2.5 \mathrm{~cm}$ まで 7 名 $(27.0 \%)$, $1.5 \mathrm{~cm}$ まで 5 名 $(19.2 \%), 3.0 \mathrm{~cm}$ まて 2 名 $(7.7$ \%)であった．次に下口唇について検討した 13 名についてみると，図18に示す如く，反対側 $2.0 \mathrm{~cm}$ まで11名 $(84.6 \%), 2.5 \mathrm{~cm}$ と $3.0 \mathrm{~cm}$ ま゙ がそれそれ1名（7.7\%）であった。

次に，各被験者における潜時の変化を，縦軸 に潜時，横軸に針電極の刺入部位の正中線加ら の距離をとりグラフにあらわすと，上口唇で は，図19に示す如くほぼ直線的に潜時が延長す るのがみられた。また，図20に示す如く，下口 唇に掠いても上口唇とほぼ同じ結果がえられ た。

次に刺激電極を耳垂下部之それから口角に向 って $5 \mathrm{~cm}$ 離れた所におき, 口輪筋を支配する顔 面神経線維の興奮伝導速度を測定した。
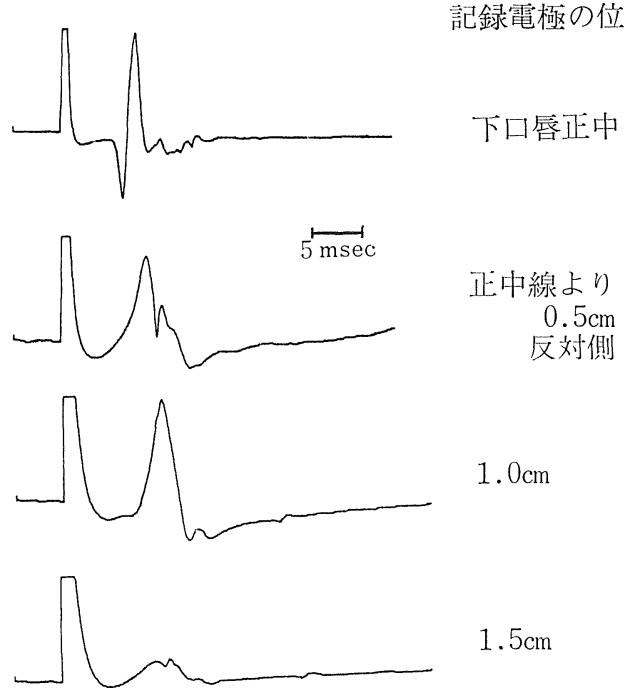

$1.5 \mathrm{~cm}$

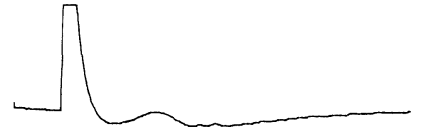

$2.0 \mathrm{~cm}$

図16 口輪筋（下口唇）における誘発筋電図 (1 針同心電極による)

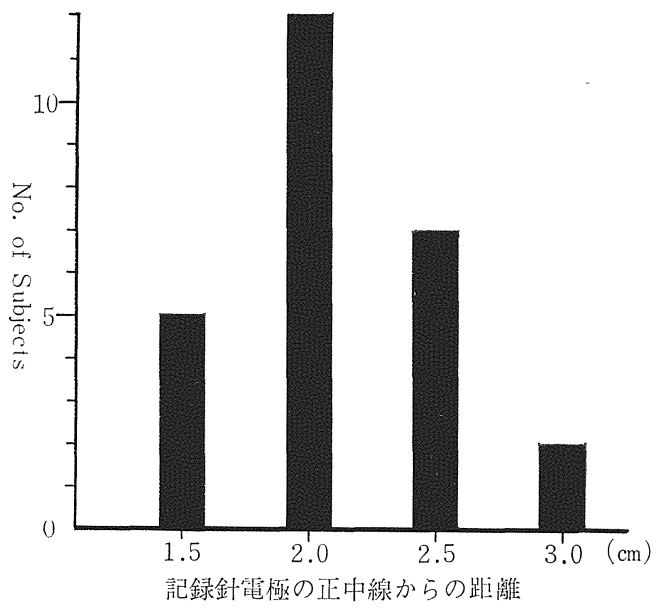

図17上口唇において反対側顔面神经刺激に対し て反応した被験者数と針電極の位置

伝導速度は

$\mathrm{CV}=\frac{\mathrm{D}}{\mathrm{T}_{1}-\mathrm{T}_{2}}$ により算出した.

但し， $\mathrm{D}: 0.05 \mathrm{~m}, \mathrm{~T}_{1}$ : 耳垂直下刺激の場合の 


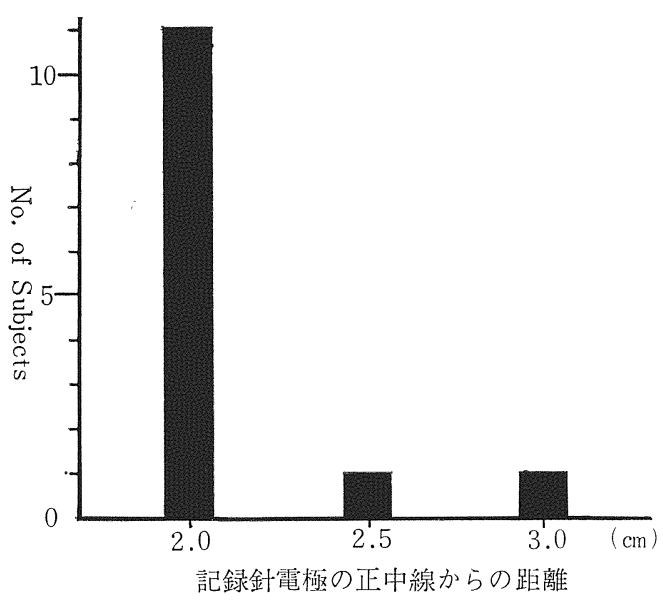

図18下口唇において反対側顔面神経刺激に対し て反応した被験者数と針電極の位置

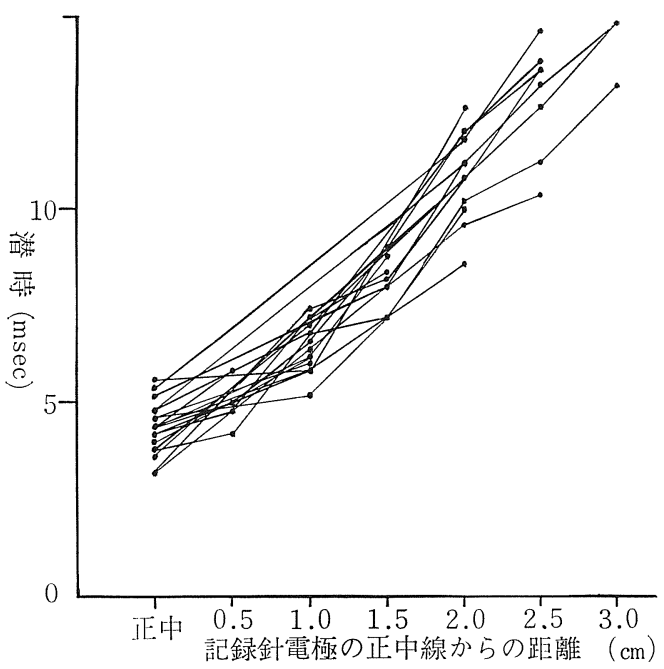

図19上口唇における誘発筋電図の潜時之記録針 電極の位置との関係

潜時, $\mathrm{T}_{2}: 5 \mathrm{~cm}$ 離れた部位における刺激の場合 の潜時,である。

図21は，上口唇における各部位で計測した興 奮伝導速度を示している。乙れでみる如く，結 果はかなりの個人間変動を示しているが，個人 内及び全体としてみると，正中線から離れるに 従って興奮伝導速度は遅くなる傾向を示した。 平均值でみると，刺激と同側の口輪筋では51. 6

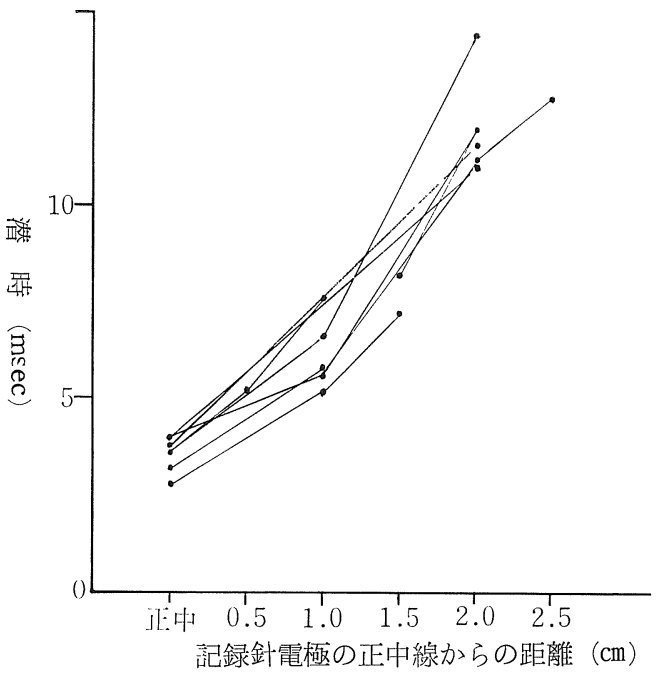

図20下口唇における誘発筋電図の潜時と記録針 電極の位置との関係

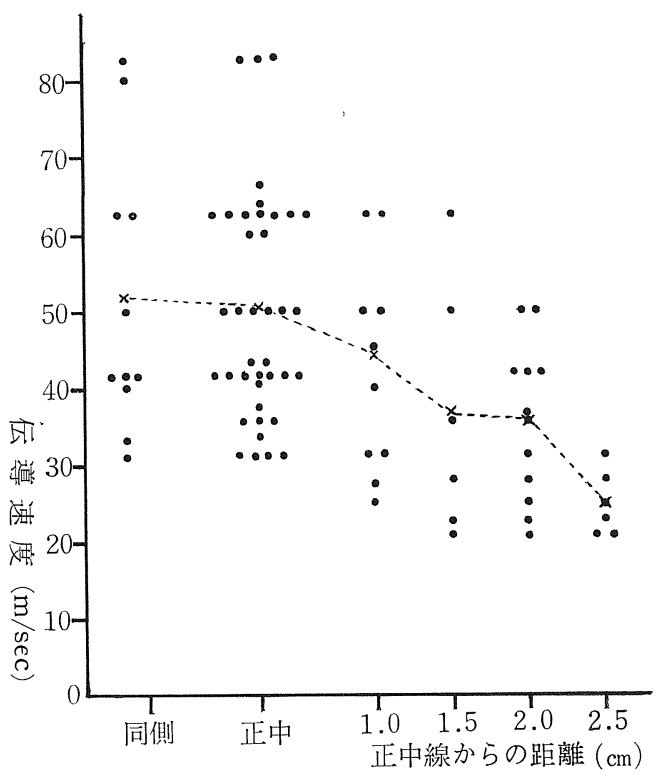

図21口輪筋 (上口唇) 支配の顔面神経線維の興 舊伝導速度

$\mathrm{m} / \mathrm{sec}$, 正中線上で $50.3 \mathrm{~m} / \mathrm{sec}$, 正中線より 1.0 $\mathrm{cm}$ 反対側で $44.2 \mathrm{~m} / \mathrm{se}, 1.5 \mathrm{~cm}$ で $36.6 \mathrm{~m} / \mathrm{sec}$, $2.0 \mathrm{~cm}$ で $35.5 \mathrm{~m} / \mathrm{sec}, 2.5 \mathrm{~cm}$ で $24.2 \mathrm{~m} / \mathrm{sec}$ で あった，次に，下口唇については，罒22に示し た如くで, 正中線上では $54.9 \mathrm{~m} / \mathrm{sec}$ 正中線より 


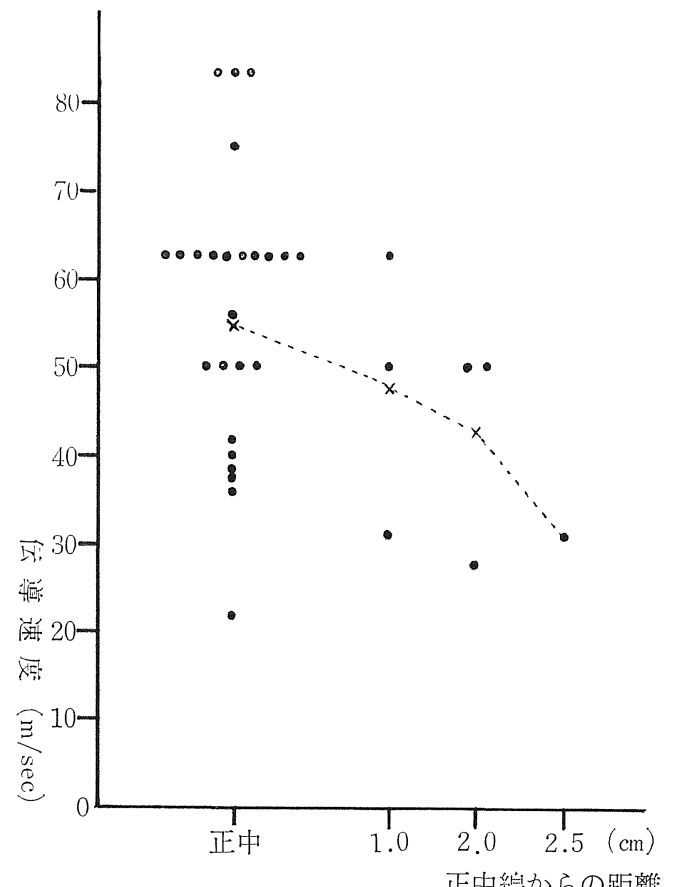

図22 口輪誘 (下口唇) 支配の顔面神経線維の興 奮伝導速度
$1.0 \mathrm{~cm}$ 反対側で $47.5 \mathrm{~m} / \mathrm{sec}, 2.0 \mathrm{~cm}$ で $42.5 \mathrm{~m} / \mathrm{sec}$ であった．下口唇に揓いても上口唇と全く同様 の結果が認められた。また，下口唇支配枝の興 舊伝導速度の平均值が上口唇のそれより高い值 を示したが，両者の間に統計的有意差々なかっ た.

以上の結果より，正常人の口輪筋では上口唇 においてあ下口唇においても, 正中線より 2 〜 $3 \mathrm{~cm}$ 離れた所迄は両側の顔面神経の支配をうけ ている事が判明した，又，反対側にのびる神経 は，正中線を越えるに従って伝導速度が遅くな る事がわかった。言いかえると，反対側にいく

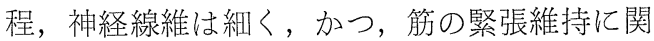
係する神経である事が推論された。

眼輪筋涙囊部においては，1 針同心電極では 反対側の顔面神経刺激に対する誘発電位の記録 はえられなかったが，表面電極では全例におい て反対側の誘発電位を認める事が出来た．眉間 部に㧊いては，正中線より $1.0 \mathrm{~cm}$ までは針電極 による誘発筋電図記録が可能であった。

\section{第四節＼cjkstart動物における検討}

人間に打ける顔面神経の反対側よりの支配 が，動物においても在存するあのであるか，ま た，あしあれば，両側顔面神経を確実に切断し てより確実な誘発筋電図及び伝導速度の検討が 可能であると考え，以下の動物実験を行った．

\section{〔実験方法】}

実験動物として体重約 $3 \mathrm{~kg}$ の成 熟家 鬼を 4 羽，体重 2.5 3 kgの独を 3 匹使用した。家鬼 に於ては，ウレタン $(1.0 \mathrm{~g} / \mathrm{kg}) ，$ クロラロー ス $(30 \mathrm{mg} / \mathrm{kg})$ 麻酔後，気管切開を行い，人工 呼吸器につけた。猫の場合，ネンブタール麻酯 （30mg/ $\mathrm{kg} ）$ を行い，同様の処置を行った。頭 部を東大脳研式万能脳固定装置に固定後，外耳 を切断し，中耳を露出した．耳小骨を除去し， バーなどで顔面神経を露出後, 脳幹部近くまで 神経を引き抜く様にして露出した。顔面神経末 梢端を双極銀電極の上にのせ，パラフィンに浸 した。顔面部を剃毛後，2 針同心電極を各部位
に刺入し，誘発筋電図記録を行った。誘発筋電 図の記録方法は第一節に述べた方法に準じた。

\section{〔実験結果〕}

図23は，家鬼に扣ける口輪筋の誘発筋電図で あり，図24は顔面皮下筋の眼下部の誘発筋電図 である。

口輪筋では，正中を越えて $1.5 \mathrm{~cm}$ 反対側まで 明らかに潜時を識別しうる誘発電位が認められ た。潜時は同側で $2.8 \mathrm{msec}$, 正中線で 3.2 $\mathrm{msec}$, 正中線より $0.5 \mathrm{~cm}$ 反対側 $4.4 \mathrm{msec}, 1.0 \mathrm{~cm}$

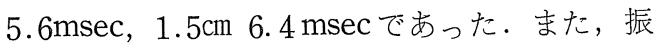
幅は正中を離れるに従い減少した。

顔面皮下筋の眼下部に拈いては図24に示した ように，正中線を越えて $1.5 \mathrm{~cm}$ の所まで誘発電 位がえられた。潜時は同側で $3.2 \mathrm{msec}$. 正中

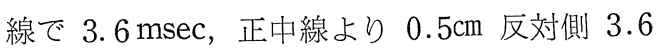
msec, $1.0 \mathrm{~cm}, 5.6 \mathrm{msec}, 1.5 \mathrm{~cm}, 7.6 \mathrm{msec}$ であ った。また，振幅は正中を離れるに従って減少 
剖録電極の位置

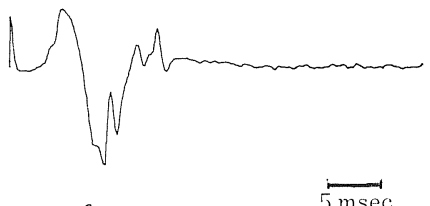

同側

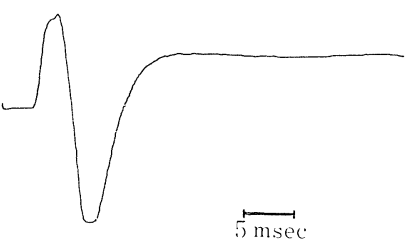

嗼録電極の位䇺

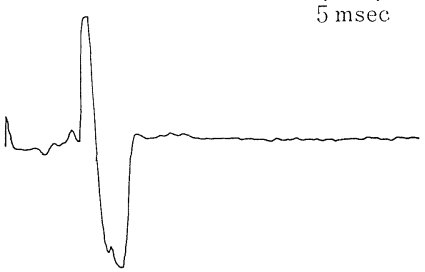

止中

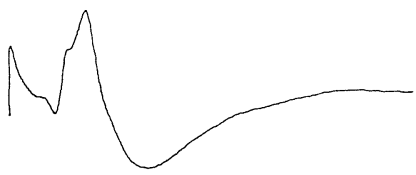

正中

正中線より

$0.5 \mathrm{~cm}$

反対側

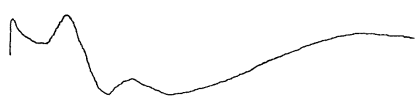

正中線より

$0.5 \mathrm{~cm}$

$1.0 \mathrm{~cm}$

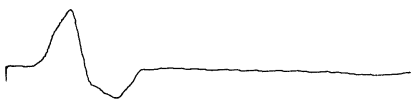

$1.0 \mathrm{~cm}$

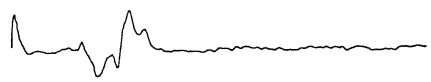

$1.5 \mathrm{~cm}$

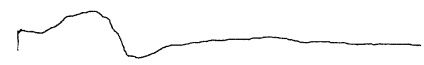

$1.5 \mathrm{~cm}$

$2.0 \mathrm{~cm}$

$2.0 \mathrm{~cm}$

図24家鬼顔面皮下筋（眼下部）誘発筋電図

図23家兔口輪筋誘発筋電図

した。

即ち，家鬼では， 口輪筋，顔面皮下筋の眼下 部に损いても，正中を越えた両側支配が認めら れた。

猫について同様の試みを行ったが，猫におい ては，皮膚が硬くて厚く，顔面筋が極めて菲薄 であり，筋の分離が困難であった。また顔面神 経刺激の submaximal range が極めて狭く，

一側顔面神経刺激に対して顔面筋全体が反応す

る為, 解析に值する誘発電位をえる事は困難で あった。

動物における実験結果から，家鬼に㧊いては 顔面神経両側支配は極めて顕著であり，むしろ 人間より屯正中部に拉ける両側性支配の役割は 大きい事が予測される。この点については更に 詳細に解剖学的電気生理学的検討がなされなけ ればならないと考えられる。

\section{参 考 文 献}

1) Fujita, T.: Über die periphere Ausbreitung : 578 614. 1934 .

\footnotetext{
原稿到着：昭和51年 2 月 26 日

別刷請求先: 西村宏子

于606 京都市左京区聖護院川原町53

京都大学医学部耳鼻咽喉科学教室
} 